\title{
Verteilungspolitische Herausforderungen der Corona-Krise
}

Die Corona-Krise hat sich insbesondere auch auf den Arbeitsmarkt ausgewirkt. Der Lockdown hat zu Arbeitsplatzverlusten geführt - allen voran in der Hotel-, Gastronomie- und Tourismusbranche. Ebenso sind bestimmte Branchen von Kurzarbeit betroffen. Das hat Folgen für die Einkommenssituation der betroffenen Haushalte. Es lässt sich zeigen, dass Haushalte mit bereits vor der Krise niedrigeren Einkommen in der Krise stärkere Einkommensverluste erleiden. Allerdings entfaltet das Konjunktur- und Krisenbewältigungspaket der Bundesregierung mit Hilfsmaßnahmen durchaus seine Wirkung, um Arbeitsplätze zu stabilisieren und soziale Härten abzufedern. Davon profitieren Männer jedoch vergleichsweise stärker als Frauen.

Das neuartige Virus trifft auf die alten Verteilungsmechanismen:

Warum die COVID-19-Pandemie zu mehr sozialer Ungleichheit führt

Christoph Butterwegge, ehem. Universität zu Köln.

Arbeitsmarkteffekte der Corona-Krise - Sind Berufsgruppen mit niedrigen Einkommen besonders betroffen?

Tanja Buch, Institut für Arbeitsmarkt- und Berufsforschung.

Silke Hamann, Institut für Arbeitsmarkt- und Berufsforschung.

Annekatrin Niebuhr, Institut für Arbeitsmarkt- und Berufsforschung.

Duncan Roth, Institut für Arbeitsmarkt- und Berufsforschung.

Georg Sieglen, Institut für Arbeitsmarkt- und Berufsforschung.

Verteilungsfolgen der Corona-Pandemie: Sozialstaatliche Sicherungssysteme und Hilfsmaßnahmen stabilisieren soziales Gefüge

Martin Beznoska, Institut der deutschen Wirtschaft.

Judith Niehues, Institut der deutschen Wirtschaft.

Maximilian Stockhausen, Institut der deutschen Wirtschaft.

Das Konjunkturpaket der Bundesregierung und seine Auswirkungen auf Frauen und Männer Claudia Wiesner, Hochschule Fulda.

Title: : Distributional Challenges of the Corona Crisis

Abstract: The coronavirus crisis has had a distinct impact on the labour market. The lockdown has led to job losses, especially in the catering and tourism industries. Certain sectors have also been affected by shortterm work. This also has consequences for the income situation of affected households. It is evident that households with incomes that were already lower before the crisis are more affected by income losses during the crisis. However, the federal government's economic stimulus and crisis management aid package is certainly effective at stabilising jobs and averting social hardship. However, men benefit from this comparatively more than women.

JEL Classification: D31, E62, H12 